\section{A study on capital budgeting practices of some selected companies in Bangladesh}

\author{
Md. Anhar Sharif Mollah, Md. Abdur Rouf and S.M. Sohel Rana \\ Department of Business Administration, Daffodil International University, \\ Dhaka, Bangladesh
}

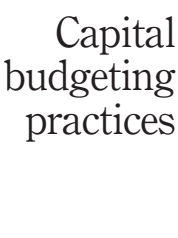

Received 21 October 2020 Revised 3 February 2021 Accepted 21 February 2021

\begin{abstract}
Purpose - The purpose of this paper is to investigate the current capital budgeting practices in Bangladeshi listed companies and provide a normative framework (guidelines) for practitioners.

Design/methodology/approach - Data were collected with a structured questionnaire survey taking from the chief financial officers (CFOs) of companies listed in the Dhaka Stock Exchange in Bangladesh. Garnered data were then analyzed using descriptive and inferential statistical techniques.

Findings - The results found that net present value was the most prevalent capital budgeting method, followed closely by internal rate of return and payback period. Similarly, the weighted average cost of capital was found to be the widely used method for calculating cost of capital. Further, results also revealed that CFOs adjust their risk factor using discount rate.

Originality/value - The findings of this study might help the firms, policymakers and practitioners to take a wise decision while evaluating investment projects. Additionally, this study's findings enrich the existing body of knowledge in the field of capital budgeting practices by providing more reliable and comprehensive analysis taking samples from a developing economy.
\end{abstract}

Keywords NPV, Risk, Financial management, Capital budgeting, IRR, WACC

Paper type Research paper

\section{Introduction}

The basic objective of financial management is the maximization of the shareholders' wealth by focusing on three decisions which are capital budgeting decisions, capital structure decision and dividend decision. Most of the scholar and practitioner opine that although three decisions are important, firm success and survival ultimately depend on a right investment decision because a good investment decision remains good business even though bad finance taken; on the contrary, a bad investment decision will be a wrong decision even with best finance policy (Brealey et al., 2015). A sound capital budgeting decision is very critical for a firm because it is aligned with the firm's primary objective (wealth maximization), and it requires a substantial amount of resource and long-term commitment. Once the decision has been made, the process cannot be manipulated without incurring losses (Hall and Millard, 2010). Capital budgeting is a major terrain of the sphere of

(C) Md. Anhar Sharif Mollah, Md. Abdur Rouf and S.M. Sohel Rana. Published in PSU Research Review. Published by Emerald Publishing Limited. This article is published under the Creative Commons Attribution (CC BY 4.0) licence. Anyone may reproduce, distribute, translate and create derivative works of this article (for both commercial and non-commercial purposes), subject to full attribution to the original publication and authors. The full terms of this licence maybe seen at http://creativecommons.org/licences/by/4.0/legalcode

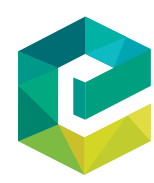

PSU Research Review Emerald Publishing Limited 2399-1747 DOI 10.1108/PRR-10-2020-0035 
financial management. Capital budgeting is related activities, it is not a standalone single activity; rather it is defined as a process called "capital budgeting process." Capital budgeting is extremely important for capital investment decisions owing to its nature of capital budgeting process. Gitman et al. (2015) define capital budgeting as "the process of evaluating and selecting long term investment consistent with the firm owners' goal of wealth maximization" (p. 344). Universally accepted definition yet to exist, because it is involved with multifaceted activities and influenced by many changing factors in the organizational environment.

Capital budgeting practices are the most vital component of financial management (Bunch, 1996) and one of the most widely investigated topic in corporate finance literature. Majority of the studies investigating the capital budgeting practices among surveyed firms are from developed economies followed by emerging economies [e.g. the USA (Graham and Harvey, 2001), Canada (Jog and Srivastava, 1995; Bennouna et al., 2010), Japan (Shinoda, 2010), the UK (Arnold and Hatzopoulos, 2000), India (Singh et al., 2012; Verma et al., 2009) and Sri Lanka (Nurullah and Kengatharan, 2015a, 2015b)]. However, in contrast to the developed world, this area is less investigated in emerging economies. Bangladesh is a rapidly growing emerging economy. Till date and as per best of our knowledge, there is no comprehensive study exploring the key aspects of capital budgeting practices by listed firms in Bangladesh. This presents an opportunity to investigate the topic under discussion for an emerging economy like Bangladesh. Therefore, the aim of this study is to fill this gap in the empirical literature by providing first-time comprehensive empirical evidence from Bangladesh.

Currently, research on capital budgeting practice has attracted scholars because of its importance and insight gained. However, in comparison with developed countries, this area is less studied in emerging economies like Bangladesh. Till date and as per the best of authors' knowledge, no major studies except Shakila (2015) has been conducted on capital budgeting practices in Bangladesh. Therefore, the purpose of this study is to investigate the current scenario of capital budgeting practices in Bangladesh and to identify the pitfalls of capital budgeting practices of listed companies in Bangladesh.

\section{Literature review}

\subsection{Defining and understanding capital budgeting}

Capital budgeting is not a stand-alone single activity related decision; rather it is a process called the "capital budgeting process." The nature of the capital budgeting process makes it extremely important in arriving at a capital investment decision. The capital budgeting process is a multifaceted activity designed to help in the selection of investment projects that are viable and worthy of pursuing. It is dynamic, not static. No all-around acknowledged agreement exists, and it is affected by many changing factors in the organizational environment. Mainly, capital budgeting process deals with planning, reviewing, analyzing, selecting, implementing and following up activities. Leon et al. (2008) pointed out that capital budgeting is a process of evaluating and decision-making on investment projects. The authors also stated that evaluation must involve the cash flows from the proposed project considering the risk and uncertainty. Thus, care must be taken in project selection to ensure a greater probability that positive results will be made in the long run to the firm.

Capital budgeting is considered an important element in the firm managerial decisions (Garrison et al., 2018) and long-term financial performance (Emmanuel et al., 2010).

Ross et al. (2016) defined capital budgeting as the ways of planning and managing the firm investment in the long-term assets. Capital budgeting also plays a vital role in the 
firm's strategic decisions like firm expansion, asset replacement and new asset selection, cost minimization and choosing between leases or buy.

\subsection{Capital budgeting techniques}

Capital budgeting method can be categorized into two groups: discounted cash flow (DCF) method and non-discounted cash flow (non-DCF) methods. Non-DCFs include payback method (PBM) and accounting rate of return (ARR). DCFs include net present value (NPV), internal rate of return (IRR), discounted payback method and profitability index (PI). While DCFs take into account the time value of money, the non-discounted methods are not considered time value of money (Alleyne et al., 2018; Hermes et al., 2007).

Haka et al. (1985) divided capital budgeting methods into two categories: sophisticated and naïve selection techniques. Sophisticated techniques consider risk adjusted net cash flows, time value of money and inflation. Sophisticated techniques are NPV, IRR and PI; on the other hand, naïve method does not consider risk adjusted factor and time value of money. Major categories of naïve methods are PBP and ARR.

According to Baker and Powell (2009), the capital budgeting process involves six stages: identifying project proposals, estimating project cash flows, evaluating projects, selecting projects, implementing projects and performing a post-completion audit. A clear explanation of capital budgeting was set forth by Segelod (1998), who said:

[...] capital budgeting is the procedures, routines, methods and techniques used to select investment opportunities, develop initial ideas into specific investment proposals, evaluate and select a project, and control the investment project to assess forecast accuracy.

\subsection{Factors influencing the selection of capital budgeting method}

According to Alles et al. (2020), selection of capital budgeting techniques can be influenced by both the financial and nonfinancial factors. The nonfinancial factors include demographic variables of the decision-maker. But Katabi and Dimoso (2016) conducted a study in Tanzania and found that business-related factors like industry of the business, sales growth, business establishment, number of employees and form of business play a vital role for selecting capital budgeting methods.

Leon et al. (2008) found eight factors that motivate them to choose a capital budgeting method in Indonesian's firm. Factors are chief financial officers' (CFOs) education, size of the firm, total annual investment, industry type, ownership structure, multinational culture and financial leverage. In addition, Brunzell et al. (2013) found one more factor which is political risk for selecting methods. Daunfeldt and Hartwig (2008) conducted a study on Swedish listed companies and found few new factors such as dividend payout ratio, potentiality of firm growth and foreign sales amount.

Nonetheless, a transformation was witnessed by the end of the 1980s wherein surveys stated that popularity of DCF methods of IRR and NPV was increasing day by day and decreasing the usage of payback period (PBP) as a primary method, while it was highly popular method as secondary criteria (Blazouske et al., 1988; Brigham, 1975; Gitman and Forrester, 1977; Farragher et al., 2001; Farragher et al., 2001).

\subsection{Prior studies on capital budgeting practices: a brief overview}

A review of the past research, of the 1960s and beginning of 1970s, stated the dominance of non-discounted techniques like PBP (Graham and Harvey), after that by ARR. During this time most of the researchers found that the DCF model was the least popular method for capital investment decision (Baker and Beardsley, 1972). But, by the end of 1980s, research 
found a changing trend regarding more use of DCF methods of NPV, IRR and started decline in the usage of non-DCF methods of PBP and IRR as primary methods but remain highly popular as secondary methods. Pike and Neale (2006) and Arnold (2008) now provide diagrams that illustrate the multistage nature of investment decision-making in firms.

Kester and Robbins (2011) conducted a survey of CFOs of listed companies on Irish Stock Exchange on capital budgeting techniques used by Irish listed companies. The results found that they use DCF methods, and NPV was the most popular measure for capital budgeting decision, followed closely by PB, and IRR was ranked third, also mentioned that ARR was the least important technique according to the respondents. Scenario analysis and sensitivity analyses were perceived to be the most prevalent tools for incorporating risk. The respondent executives also indicated that they use a single discount rate based on weighted average cost of capital (WACC) that was the most widely accepted method used for calculating discount rate. On the other hand, Lazaridis (2004) studied capital budgeting practices in Cyprus, and PB was found to be the most prevalent method, but not NPV.

Shinoda (2010) conducted a survey focusing on capital budgeting practices in Japan taking sample data from 225 companies listed on the Tokyo Stock Exchange. The results found that Japanese firms manage their capital budgeting decisions by a combination of PB and NPV methods. The capital budgeting techniques used depend on the subject and situation. Effective decision-making with regard to capital budgeting requires a more multifaceted approach to the issue of capital budgeting methods rather than rigorous academic theory.

Over the past two decades, very few studies have been conducted on the capital budgeting practices in the developing countries. Compared to developed countries, the results of most studies show inconsistencies. In most developing countries, the PB method was the most popular method in evaluating investment projects. Kester et al. (1999) conducted a survey on 226 companies considering six countries: Australia, Hong Kong, Indonesia, Malaysia, the Philippines and Singapore. Their results indicated that PBP is the most used method and that DCF methods have become increasingly popular. In five Asian countries, $95 \%$ of firms used the PB method and $88 \%$ used the NPV in evaluating projects. However, PBP and NPV methods were equally popular. The rate of capital asset pricing model (CAPM) is more used in Australia compared with other countries considered for the adjustment of risk.

Hermes et al. (2007) conducted a comparative study of Dutch and Chinese firms taking data from a survey among 250 Dutch and 300 Chinese firms with regard to their capital budgeting practices. In total $89 \%$ of the Dutch CFOs reported that NPV method is the most popular method followed by PBP, but ARR method is the clearly least popular in Dutch. In total $66.7 \%$ of the Dutch CFOs stated that they used WACC and only $9.5 \%$ of them used PDCC. Small firms used cost of debt (CD) most often (22.7\%) in comparison with larger firms $(5.0 \%)$. In contrast, $53.3 \%$ of the Chinese firms indicated that they used WACC, and just $15.7 \%$ of the CFOs of Chinese firms used PDCC. However, $28.90 \%$ of the CFOs reported that they used CD, which was more than their Dutch counterparts. The Chinese CFOs stated that they were more likely to use NPV and PB methods ( $89 \%$ and $84 \%$, respectively) in evaluating capital budgeting projects. Hence, Dutch CFOs usually use more sophisticated capital budgeting techniques compared to Chinese CFOs.de Andrés et al. (2015) conducted a survey with a sample of 140 nonfinancial Spanish firms to shed further light on the capital budgeting techniques used by Spanish companies. Primarily payback was the most widely used tool, while real options were used relatively little. Furthermore, their results confirmed that a firm's size and industry were related to the frequency of use of certain capital 
budgeting techniques. Finally, they found that the relevance of growth opportunities and flexibility was an important factor in explaining the use of real options.

Mubashar and Tariq (2019) carried out a study on 200 nonfinancial firms listed on Pakistan Stock Exchange, with a response rate of 35\%. It was found that Pakistani listed firms frequently used NPV, IRR and PI for capital budgeting. Out of these DCF methods, NPV is the most used method (61.4\% of respondent firms always use NPV) of capital budgeting. Again, 27\% firms always used IRR, but interestingly all the respondents firms use IRR with NPV as a secondary method. Similarly, WACC is estimated using target value weights, and capital asset pricing model (with extra risk factors) is used to determine the cost of equity capital. For risk assessment, sensitivity analysis and scenario analysis are the dominant approaches; however, despite the theoretical superiority, the use of real options is very low. Overall, investment decision responses significantly differ across firms' demographics and executive characteristics.

Baker et al. (2017) based on the survey on 75 listed companies of Morocco revealed that $64 \%$ firms used IRR, 63\% ARR and 53\% PBM but NPV is least popular method in Morocco. Few of the responding firms use real options when making capital budgeting decisions. They tend to use less sophisticated techniques to evaluate investment opportunities and calculate the cost of capital than their counterparts in developed countries. The most frequently used techniques by Chittagong Stock Exchange-listed companies to estimate the cost of equity capital are the CD plus equity risk premium and the accounting return on equity. Alleyne et al. (2018) conducted a study on 41 firms in Barbados. The study suggested that firms in Barbados are not likely to use capital budgeting practices in project selection. Majority of respondents list the PBM as the preferred capital budgeting method to be used owing to simplicity, ease of calculation, possibility of less effort and agility of the methods. Results also showed that most organizations use "crude methods" and nontraditional methods of capital budgeting to aid decision-making. While there are no statistically significant differences in the capital budgeting practices used in different sectors, professional accountants are more likely to use NPV and sensitivity analysis than nonprofessional accountants.

Nurullah and Kengatharan (2015a) conducted a comprehensive primary survey of 32 out of 46 CFOs of manufacturing and trading companies listed on the Colombo Stock Exchange in Sri Lanka. The results revealed that NPV was the most used capital budgeting method, followed closely by PBP and IRR. Similarly, for incorporating risk, sensitivity analysis was considered as the dominant capital budgeting tool, and the most preferred method for calculating cost of capital was the WACC. Moreover, results stated that the use of the capital budgeting methods (NPV, IRR and PB) and incorporating risk tool were (sensitivity analysis and simulation) influenced by size of the capital budget.

Andor et al. (2015) conducted a comprehensive phone survey of 400 CEOs of small, medium and large firms in ten countries of Central and Eastern Europe (CEE). They concluded that capital budgeting practices of CEE are mostly affected by firm size, culture and country's code of ethics and firm objectives, while targeted leverage, management ownership and number of projects to be analyzed also play a moderate role. The same is true for calculating the cost of capital and the use of CAPM. Large firms used $56 \%$ DCF method which is more than small and medium enterprises (45\%). Surprisingly, study revealed that even though advanced capital budgeting practices including DCF, sensitivity analysis and real options are available, still top management can reject a handsome project that was once chosen based on DCF methods owing to several other factors such as ethical and moral considerations, financial resources scarcity, strategic fit, trust in the analysts or reliable sources of data. 
Bennouna et al. (2010) stated that the Canadian firms preferred to use NPV but still show a gap between theory and practice. Moreover, $17 \%$ of large firms did not use DCF. Of those, the majority of the Canadian firms used NPV and IRR, and only $8 \%$ preferred real options. The result shows a theory-practice gap remains in the detailed elements of DCF capital budgeting decision techniques and in real options.

Khamees et al. (2010) conducted a study on the Jordan Industrial Corporation and found that firms used equal percentages of DCF and non-DCF methods in evaluating capital investment projects. Results also reported that the most popular method is the PI followed by the PBP. The results revealed that respondents do not depend on a single technique. However, the results did not state that DCF or non-DCF cash flow methods are preferred over the other methods. On other hand, the PI technique was the most used technique followed closely by the PBP.

De Souza and Lunkes (2016) investigated the use of capital budgeting practices by large Brazilian publicly traded companies. Their findings reveal that managers of Brazilian companies mostly used the PB (71\%) followed closely by NPV (65\%) and (IRR) (61\%). The study also reports that the most frequent practice used in setting the minimum rate of return is WACC $(63 \%)$. For assessing risk, the results show that the most widely used techniques are scenario analysis (68\%) and sensitivity analysis (55\%).

Batra and Verma (2017) examined responses from 77 Indian companies listed on the Bombay Stock Exchange. Their evidence reveals that corporate managers largely follow the capital budgeting practices proposed by academic theory. DCF techniques of NPV and IRR and risk-adjusted sensitivity analysis are the most popular. Managers also favor WACC as the cost of capital. Yet, the theory-practice gap exists in adopting specialized techniques of real options, modified internal rate of return (MIRR) and Nurullah and Kengatharan (2015b) simulation. Managers also consider nonfinancial criteria in selecting projects.

\section{Methodology}

The nature of this study allowed for the use of an explanatory sequential mixed method design, by collecting quantitative data and to further explain it using qualitative research. This allowed for the researchers and end users of the final report to be provided with general data and also enabled them to develop a greater understanding of the reasons for the decisions (Creswell, 2014). For this reason, open-ended questions were also included within the survey instrument. This allowed the respondents to write down their opinions, and at the same time, the researchers were able to obtain answers to "why, what and how" (Saunders et al., 2007). The reliability of the responses from the survey phase was tested with follow-up interviews. These interviews were scheduled and used to clarify issues and gather additional information regarding the reasons why the techniques (practices) documented within the questionnaire are (not) used and determine what techniques are being used.

This is an exploratory study using survey methodology to collect data regarding current practices of capital budgeting in Bangladesh. The population included 285 firms listed in Dhaka Stock Exchange (DSE). The questionnaire used to collect data was adopted from previous seminal studies (Nurullah and Kengatharan, 2015b). The questionnaires were sent to the top DSE 100 companies in terms of market capitalization. The DSE100 indexed firms were chosen because they are representatives of DSE. The questionnaires were sent to the company's $\mathrm{CFO}$ and director finance through email. The email addresses were fetched from the official website of DSE and company's respective website. The initial response rate was very poor; only seven firms responded. Subsequently, reminders were sent to the remaining companies through email and by the help of Chartered accountant Association. Out of 100 companies 46 firms responded, the response rate is $46 \%$. 
Collected data were presented and analyzed using descriptive and inferential statistics. Data were presented in terms of firm background, CFO/finance director background, purpose of using capital budgeting and cause of using different techniques in investment decisions.

\section{Capital budgeting practices}

\section{Results and analysis}

\subsection{Educational qualification of the chief financial officers/finance directors}

Classification of the educational qualification of the CFOs was grouped into: bachelor degree, MBA, non-MBA Master's, above Master's degree and professional qualification (e.g. CA, CIMA and ACCA). Professional degree was held by $51.28 \%$ of CFOs, followed by MBA qualification (33.33\% non-MBA Master's 10.26\%). Above Master's degree respondents are $5.13 \%$, as per Table 1 .

\subsection{Experience of the chief financial officers}

CFOs' experience is categorized into three groups based on the number of years they worked in a particular profession. In this study, $30.77 \%$ (12) of CFOs have working experience of more than 20 years. In total $48.72 \%$ (19) of CFOs have working experience between 11 and 20 years, and finally $20.51 \%$ (9) CFOs have working experience of below ten years. Results are depicted in Table 2.

\subsection{Firms' size of the capital}

Size of the capital budget has been categorized into five groups which are presented in Table 3. The size generally takes a minimum of ten million and a maximum of more than one billion. In total $20.51 \%$ of companies' size of the capital budget is less than ten million, while only $5.13 \%$ represented for more than one billion; $25.64 \%$ of companies' capital budget is between 10 and 100 million. A total of 14 companies $(35.89 \%)$ mentioned their size of the capital budget is 100-200 billion, and rest of the companies $(15.22 \%)$ falls between 200 and 300 million.

\begin{tabular}{|c|c|c|c|}
\hline Educational qualification & No. of CFOs/finance director $(N)$ & $(\%)$ & \\
\hline Bachelor degree & 0 & 0 & \\
\hline MBA & 13 & 33.33 & Table 1. \\
\hline Non-MBA Master's & 4 & 10.26 & Classification of \\
\hline Professional qualification & 20 & 51.28 & educational \\
\hline Above Master's degree & 2 & 5.13 & qualification of $\mathrm{CFO} /$ \\
\hline Total & 39 & 100 & finance director \\
\hline
\end{tabular}

\begin{tabular}{lccc}
\hline CFO/finance directors experience (years) & No. of company $(N)$ & $(\%)$ & \\
\hline Less than 10 years & 8 & 20.51 & Table 2. \\
11-20 years & 19 & 48.72 & Classification of \\
More than 20 years & 12 & 30.77 & CFOs experience \\
Total & 39 & 100 & . \\
\hline
\end{tabular}


As per Table 4, among the 39 firms, $35.89 \%$ (14) firms take capital budget plan before three years ahead followed by $23.08 \%$ (nine firms take decision one year ahead). Also seen $17.95 \%$ (7) took their capital budgeting decision two years before. Meanwhile, five firms taking capital budgeting decision four four years ahead and four firms taking capital budgeting decision more than five years ago.

4.5 Purpose of capital budgeting methods

To analyze the purpose of capital budgeting (Table 5), $46.15 \%$ of CFOs $(N=18)$ describe that the dominant motivation for making investment is for expansion into existing business only. In all $17.95 \%$ of CFOs reported that their main purpose for capital budget is for expansion of new business only, $15.38 \%$ of CFOs indicated for expansion of new facilities,

\section{Table 3.}

Classification of firms' size of capital

Size of the capital budget

No. of company $(N)$ $(\%)$

Less than 10 million 10-100 million

100-200 million

200-300 million

More than 1 billion

Total

\section{Table 4.}

Company's planning horizon for capital expenditure budget

\begin{tabular}{lcc}
\hline Planning horizon for capital budget (years) & No. of company $(N)$ & $(\%)$ \\
\hline 1 year ahead & 9 & 23.08 \\
2 years ahead & 7 & 17.95 \\
years ahead & 14 & 35.89 \\
4 years ahead & 5 & 12.82 \\
years or more & 4 & 10.26 \\
Total & 39 & 100 \\
\hline
\end{tabular}

Table 5.

Purpose of the firms' capital budgeting

\begin{tabular}{lcc}
\hline Purpose of investment & No. of company $(N)$ & $(\%)$ \\
\hline Expansion into new business & 7 & 17.95 \\
Investing new facilities & 6 & 15.38 \\
New product development & 0 & 0 \\
Expansion of existing business & 18 & 46.15 \\
Diversification & 0 & 0 \\
Merger and acquisition & 3 & 7.69 \\
Equipment replacement & 5 & 12.82 \\
Modernization & 0 & 0 \\
Enjoying new technology & 0 & 0 \\
Research and development & 0 & 0 \\
Training and development & 0 & 0 \\
Any other capital project & 0 & 0 \\
Total & 39 & 100 \\
\hline
\end{tabular}


$12.82 \%$ of CFOs reported for equipment replacement, but $7.69 \%$ considered capital budgeting for merger and acquisition purpose. The results are almost similar to those of Verma et al. (2009).

\section{Capital budgeting practices}

\subsection{Capital budgeting methods in practice}

The respondents were also asked to indicate whether capital budgeting methods are used as primary methods, secondary methods or neither. Results are shown in Table 6 . In total $71.79 \%$ of the CFOs indicated that NPV is used as the primary method for capital budgeting decisions. Whereas $53.85 \%$ and $48.71 \%$ of CFOs reported that PBP and IRR are used as primary methods, respectively. Surprisingly, it is also shown that $41.03 \%$ of CFOs considered personal judgment as primary capital budgeting decisions. The most prevalent secondary method is the PBP $(46.15 \%)$ followed by PI, IRR, MIRR, personal judgment, discount payback period and ARR.

The results in Table 6 indicate that NPV, IRR and PBP are the most frequently used methods of capital budgeting by Bangladeshi listed companies. Out of these methods, NPV is the most popular method of capital budgeting where $74.36 \%$ of CFOs "always" prefer NPV whose yielding mean is $4.67(N=29)$. On the other hand, IRR is "always" used method by $48.71 \%$ CFOs whose mean is $4.33(N=19)$, followed by PBP $(46.15 \%)$ and personal judgment $(41.07 \%$ ) used "always" by CFOs, respectively. The results also reported that IRR is an "often" preferred method considered by the $38.46 \%$ CFOs among all the methods followed by PBP (35.89\%). The rest of the methods are not popular with the CFOs in Bangladesh. The results are consistent with Mubashar and Tariq (2019); Nurullah and Kengatharan (2015a); and Verma et al. (2009).

\subsection{Factors determining capital budgeting methods}

The finance theory describes that NPV is technically superior to IRR (Mubashar and Tariq, 2019). This research result also reported that theory and practice gap is very minimum among the listed companies in Bangladesh where the most popular method is NPV. This result is also relevant with Arnold and Hatzopoulos (2000) but not consistent with that of De Souza and Lunkes (2016).

\subsection{Cost of capital calculating methods}

The minimum required rate of return, i.e. cost of capital or discount rate is considered very important for calculating DCF methods (NPV, IRR, PI, MIRR) which involve time value of money. The CFOs were asked about the methods of calculating cost of capital on a Likert scale from "never" (1) to "always" (5). Results are presented in Table 7. The majority of CFOs

\begin{tabular}{|c|c|c|c|c|c|c|c|}
\hline Capital budgeting techniques & $\begin{array}{l}\text { Primary met } \\
\text { No. of company }\end{array}$ & $\begin{array}{l}\text { hod } \\
\qquad(\%)\end{array}$ & $\begin{array}{l}\text { Secondary me } \\
\text { No. of company }\end{array}$ & $\begin{array}{l}\text { thod } \\
\qquad(\%)\end{array}$ & $\begin{array}{c}\text { Neither } \\
\text { No. of company }\end{array}$ & $(\%)$ & \\
\hline Personal judgment & 16 & 41.03 & 14 & 35.89 & 9 & 23.08 & \\
\hline Payback period & 21 & 53.85 & 18 & 46.15 & 0 & 0 & \\
\hline Discounted payback period & 6 & 15.38 & 12 & 30.77 & 21 & 53.85 & \\
\hline Accounting rate of return & 5 & 12.82 & 12 & 30.77 & 22 & 56.41 & Table 6. \\
\hline Net present value (NPV) & 28 & 71.79 & 11 & 28.21 & 0 & 0 & Purpose of the firms' \\
\hline Internal rate of return & 19 & 48.71 & 16 & 41.03 & 4 & 10.26 & capital budgeting, \\
\hline Profitability index (PI) & 3 & 7.69 & 17 & 43.59 & 19 & 48.72 & primary vs. \\
\hline MIRR & 4 & 10.26 & 15 & 38.46 & 20 & 51.28 & secondary \\
\hline
\end{tabular}




\section{PRR}

Table 7.

Use/preference of capital budgeting techniques for the project appraisal

\begin{tabular}{lccccccc}
\hline Capital budgeting methods & Never & Rarely & Sometimes & Often & Always & Mean & Rank \\
\hline Personal judgment & $15.38 \%$ & $12.83 \%$ & $15.39 \%$ & $15.38 \%$ & $41.03 \%$ & 3.54 & 4 \\
& 6 & 5 & 6 & 6 & 16 & & \\
Payback period & $05.13 \%$ & $0 \%$ & $12.83 \%$ & $35.89 \%$ & $46.15 \%$ & 4.17 & 3 \\
& 2 & 0 & 5 & 14 & 18 & & \\
Discounted payback period & $23.07 \%$ & $5.13 \%$ & $17.95 \%$ & $23.08 \%$ & $30.77 \%$ & 3.33 & 6 \\
& 9 & 2 & 7 & 9 & 12 & & \\
Accounting rate of return & 43.59 & $23.08 \%$ & $15.39 \%$ & $10.26 \%$ & $7.69 \%$ & 2.15 & 8 \\
& 17 & 9 & 6 & 4 & 3 & & \\
Net present value (NPV) & $0 \%$ & $0 \%$ & $7.69 \%$ & $17.95 \%$ & $74.36 \%$ & 4.67 & 1 \\
& 0 & 0 & 3 & 7 & 29 & & \\
Internal rate of return & $0 \%$ & $2.56 \%$ & $10.26 \%$ & $38.46 \%$ & $48.71 \%$ & 4.33 & 2 \\
& 0 & 1 & 4 & 15 & 19 & & \\
Profitability index (PI) & $15.40 \%$ & $30.77 \%$ & $12.83 \%$ & $23.08 \%$ & $17.95 \%$ & 2.97 & 7 \\
MIRR & 6 & 12 & 5 & 9 & 07 & & \\
& $17.95 \%$ & $5.13 \%$ & $20.51 \%$ & $23.08 \%$ & $33.33 \%$ & 3.48 & 5 \\
& 7 & 2 & 8 & 9 & 13 & & \\
\hline
\end{tabular}

$(53.85 \%)$ reported that WACC is the most prevalent method to evaluate their investment project which is yielding mean value of $4.18(N=21)$ followed by the $\mathrm{CD}$ which is the next "always" widely used method to calculate cost of capital, the value is $15.38 \%(M=3.15)$. The results also indicated that $\mathrm{CD}$ is an "often" preferred method considered by $33.33 \%$ CFOs among all other methods. The remaining methods (CAPM cost of equity, arbitrary rate and average historical return) are least preferred methods by the CFOs of listed companies in Bangladesh. The previous studies by Mubashar and Tariq (2019); Nurullah and Kengatharan (2015a); Arnold and Hatzopoulos (2000); and Khamees et al. (2010) also found the same results (Table 9).

\subsection{Factors determining capital budgeting methods}

Table 8 summarized the results of determining factors of capital budgeting method. In all $48.72 \%$ CFOs reported that, "importance of the project" is the most prevalent factor for determining capital budgeting method whose mean value is $M=4.08$. This was followed by "experience and competency" (43.5 and "finance theory" 38.46\%). However, 38.46\% CFOs considered top management familiarity as "important factors," but remaining two factors,

\begin{tabular}{lccccccc}
\hline Methods of derive the cost of capital & Never & Rarely & Sometimes & Often & Always & Mean & Rank \\
\hline Weighted average cost of capital (WACC) & $2.56 \%$ & $7.69 \%$ & $12.82 \%$ & $23.08 \%$ & $53.85 \%$ & 4.18 & 1 \\
& 1 & 3 & 5 & 9 & 21 & & \\
& $10.26 \%$ & $23.08 \%$ & $35.90 \%$ & $7.69 \%$ & $17.95 \%$ & 2.97 & 3 \\
CAPM model & 4 & 9 & 14 & 5 & 7 & & \\
& $17.95 \%$ & $12.82 \%$ & $20.51 \%$ & $33.33 \%$ & $15.38 \%$ & 3.15 & 2 \\
Cost of debt (CD) & 7 & 5 & 8 & 13 & 6 & & \\
& $23.08 \%$ & $17.95 \%$ & $28.21 \%$ & $17.75 \%$ & $7.69 \%$ & 2.79 & 4 \\
Cost of equity (CE) & 9 & 7 & 11 & 7 & 5 & & \\
& $46.15 \%$ & $35.90 \%$ & $7.69 \%$ & $5.13 \%$ & $0 \%$ & 1.77 & 6 \\
Arbitrary rate (AR) & 18 & 14 & 5 & 2 & 0 & & \\
& $43.59 \%$ & $38.46 \%$ & $10.27 \%$ & $7.69 \%$ & $0 \%$ & 1.82 & 5 \\
Average historical return & 17 & 15 & 4 & 3 & 0 & & \\
\end{tabular}

Table 8.

Calculating methods of cost of capital

Average historical return 


\begin{tabular}{|c|c|c|c|c|c|c|c|c|}
\hline $\begin{array}{l}\text { Factors influencing the choice } \\
\text { of capital budgeting methods }\end{array}$ & $\begin{array}{l}\text { Not at all } \\
\text { important }\end{array}$ & $\begin{array}{l}\text { Not that } \\
\text { important }\end{array}$ & Neutral & Important & $\begin{array}{l}\text { Very } \\
\text { important }\end{array}$ & Mean & Rank & $\begin{array}{l}\text { Capital } \\
\text { budgeting }\end{array}$ \\
\hline Finance theory & $\begin{array}{l}7.69 \% \\
3\end{array}$ & $\begin{array}{c}10.26 \% \\
4\end{array}$ & $\begin{array}{l}12.82 \% \\
5\end{array}$ & $\begin{array}{l}30.77 \% \\
12\end{array}$ & $\begin{array}{l}38.46 \% \\
15\end{array}$ & 3.82 & 3 & \\
\hline Experience and competency & $\begin{array}{l}5.13 \% \\
2\end{array}$ & $\begin{array}{l}7.69 \% \\
3\end{array}$ & $\begin{array}{l}15.38 \% \\
6\end{array}$ & $\begin{array}{l}28.21 \% \\
11\end{array}$ & $\begin{array}{l}43.58 \% \\
17\end{array}$ & 3.97 & 2 & \\
\hline Informal rule of thumb & $\begin{array}{l}41.03 \% \\
16\end{array}$ & $\begin{array}{l}23.08 \% \\
9\end{array}$ & $\begin{array}{c}17.95 \% \\
7\end{array}$ & $\begin{array}{c}10.26 \% \\
4\end{array}$ & $\begin{array}{l}7.69 \% \\
3\end{array}$ & 1.72 & 6 & \\
\hline Importance of the project & $\begin{array}{r}0 \% \\
0\end{array}$ & $\begin{array}{l}12.82 \% \\
5\end{array}$ & $\begin{array}{c}15.38 \% \\
6\end{array}$ & $\begin{array}{l}23.08 \% \\
9\end{array}$ & $\begin{array}{l}48.72 \% \\
19\end{array}$ & 4.08 & 1 & \\
\hline Easy understandability & $\begin{array}{l}20.51 \% \\
8\end{array}$ & $\begin{array}{l}19.95 \% \\
7\end{array}$ & $\begin{array}{l}28.21 \% \\
11\end{array}$ & $\begin{array}{l}17.95 \% \\
7\end{array}$ & $\begin{array}{c}15.38 \% \\
6\end{array}$ & 2.90 & 5 & $\begin{array}{r}\text { Table } 9 . \\
\text { Factors influencing }\end{array}$ \\
\hline Top management familiarity & $\begin{array}{l}7.69 \% \\
3\end{array}$ & $\begin{array}{c}10.26 \% \\
4\end{array}$ & $\begin{array}{l}12.82 \% \\
5\end{array}$ & $\begin{array}{l}38.46 \% \\
15\end{array}$ & $\begin{array}{l}30.77 \% \\
12\end{array}$ & 3.74 & 4 & $\begin{array}{l}\text { the choice of capital } \\
\text { budgeting methods }\end{array}$ \\
\hline
\end{tabular}

i.e. rule of thumb and easy understandability, are not important for deciding capital budgeting decisions whose mean value is less than 3.00 .

\subsection{Problems or difficulties in capital budgeting practices}

In response to questions on the problems of capital budgeting practice used by CFOs, the survey found that $51.28 \%$ of companies are "highly influenced" by high fixed cost to practice capital budgeting method among the sample companies followed by "variation of cash flow pattern." It is revealing to note that $35.90 \%$ CFOs reported that political instability is an "influential" factor for practicing capital budgeting methods (Figure 1).

\subsection{Risk factors and adjustments}

Researchers asked the CFOs whether they adjust cash flows or discount rate for the different types of risk. The survey results Figure 2 reported that for the majority of the respondents $(53.85 \%)$, risk of unexpected inflation is adjusted by discount rate followed by interest rate risk adjusted by discount rate $(4.72 \%)$. However, commodity price risk is significantly

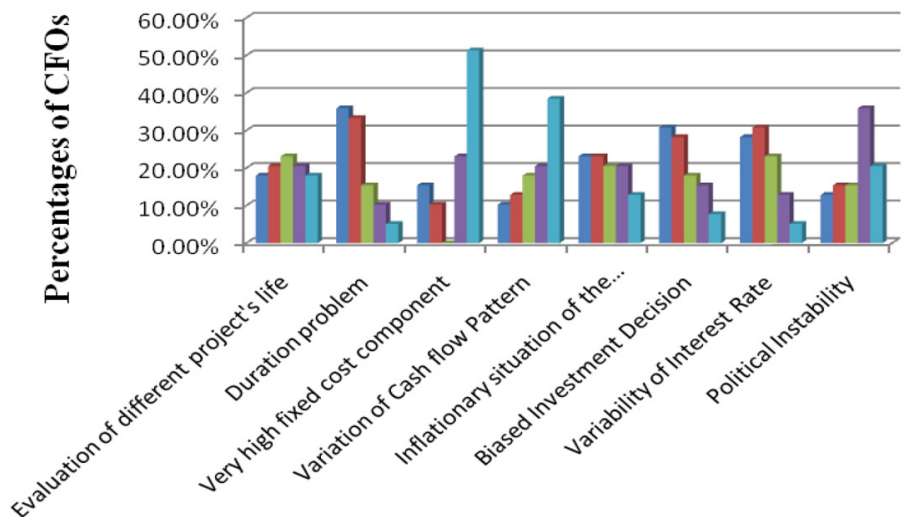

Problems of capital budgeting practices

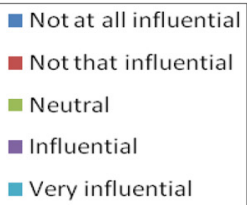

Not at all influential Not that influential - Neutral

- Influential

- Very influential

Figure 1. Problems of capital budgeting practice 


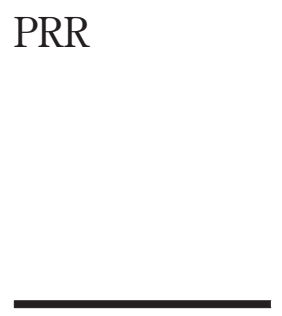

Figure 2.

Adjustment of either the discount rate or cash flows for the risk factor

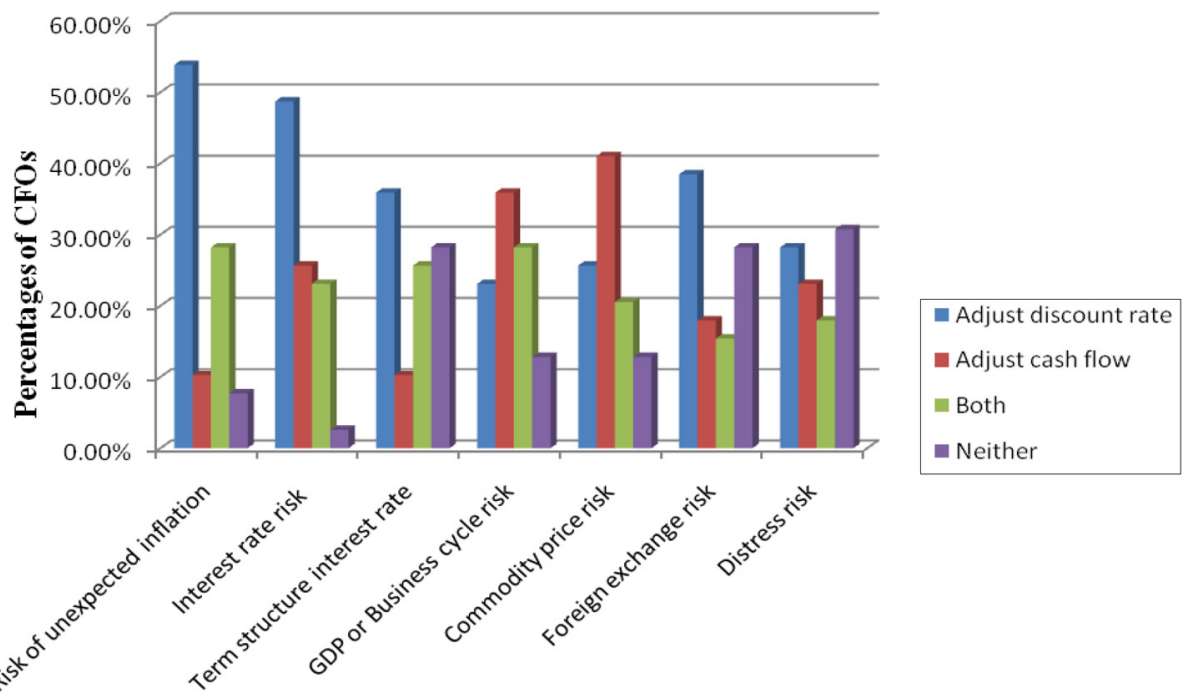

Risk Factors and Adjustments

$(43.03 \%)$ adjusted by the cash flows. The survey results are consistent with those of Batra and Verma (2017), Graham and Harvey (2001); and Nurullah and Kengatharan (2015a).

\section{Conclusion and recommendations}

The main purpose of this study is to investigate the current practices of capital budgeting methods based on 39 sample listed firms in DSE, Bangladesh. The result revealed that almost two-third of the CFOs use NPV method for evaluating investment projects and closely followed by IRR and PBP methods, respectively. Survey results also found that "importance of the project" is the most influential factor for choosing a capital budgeting method.

For calculating cost of capital or minimum required rate of return, WACC is the most preferred method among the samples listed firms. The results also found that the majority of the respondents face the main pitfall for capital budgeting practice because of the high fixed cost component in Bangladesh. Generally, risk factors including the risk of unexpected inflation, interest rate risk, term structure risk, GDP or business cycle risk, commodity price risk and foreign exchange risk were adjusted by either increasing the discount rate or reducing cash flows or both. Bangladeshi firms mainly use discount rate for adjusting the risk of unexpected inflation, interest rate risk and foreign exchange.

This study has several limitations. First, the sample is small and thus the generalization of these results should be done with caution. Future studies should target larger samples, specifically to determine other industry and firm factors that influence the use of capital budgeting practices. Additionally, the study used self-administered questionnaires and interviews across a sample of firms in Bangladesh. More in-depth analysis can be obtained via the use of multiple case studies in specific sectors. Furthermore, this current study looked at a variety of sectors rather than specific sectors. Future research can target specific problematic sectors to determine the capital budgeting practices suitable for success. Nonetheless, despite these limitations, the current study addresses key issues on capital 
budgeting practices in small emerging contexts. While we did not test for the impact of the choice of an accounting policy or method which can influence the financial position of firms, we believe that future work can specifically explore its impact on capital budgeting practices. Based on the findings of this study, the following recommendations are made:

Capital
budgeting
practices

- Majority of the respondents relied more on NPV and IRR, but firms can use real option because it is more valuable in an uncertain environment and also gives flexibility in changing the course of the project.

- Consider qualitative factors for capital budgeting practices.

- Bangladesh is now a digitized country so it is better to use more information technology and its application in the capital budgeting process.

\section{References}

Alles, L., Jayathilaka, R., Kumari, N., Malalathunga, T., Obeyesekera, H. and Sharmila, S. (2020), "An investigation of the usage of capital budgeting techniques by small and medium enterprises", Quality and Quantity, pp. 1-14

Alleyne, P., Armstrong, S. and Chandler, M. (2018), "A survey of capital budgeting practices used by firms in Barbados”, Journal of Financial Reporting and Accounting, Vol. 16 No. 4, pp. 564-584.

Andor, G., Mohanty, S.K. and Toth, T. (2015), "Capital budgeting practices: a survey of Central and Eastern European firms”, Emerging Markets Review, Vol. 23, pp. 148-172.

Arnold, G. (2008), Corporate Financial Management, Pearson Education.

Arnold, G.C. and Hatzopoulos, P.D. (2000), "The theory-practice gap in capital budgeting: evidence from the United Kingdom", Journal of Business Finance \& Accounting, Vol. 27 Nos 5/6, pp. 603-626.

Baker, J.C. and Beardsley, L. (1972), "Capital budgeting by US multinational companies”, The Financial Review, Vol. 7 No. 1, pp. 115-121.

Baker, H.K. and Powell, G. (2009), Understanding Financial Management: A Practical Guide, John Wiley and Sons.

Baker, H.K., Jabbouri, I. and Dyaz, C. (2017), “Corporate finance practices in Morocco”, Managerial Finance, Vol. 43 No. 8, pp. 865-880.

Batra, R. and Verma, S. (2017), "Capital budgeting practices in Indian companies", IIMB Management Review, Vol. 29 No. 1, pp. 29-44.

Bennouna, K., Meredith, G.G. and Marchant, T. (2010), "Improved capital budgeting decision making: evidence from Canada", Management Decision, Vol. 48 No. 2, pp. 225-247.

Blazouske, J., Carlin, I. and Kim, S.H. (1988), "Current capital budgeting practices in Canada", CMA Magazine, Vol. 62, pp. 51-54.

Brealey, R.A., Myers, S.C., Allen, F., Soria, L.N. and Izquierdo, M.Á.F. (2015), Principios de Finanzas Corporativas, McGraw-Hill Interamericana.

Brigham, E.F. (1975), "Hurdle rates for screening capital expenditure proposals", Financial Management, Vol. 4 No. 3, pp. 17-26.

Brunzell, T., Liljeblom, E. and Vaihekoski, M. (2013), "Determinants of capital budgeting methods and hurdle rates in Nordic firms", Accounting and Finance, Vol. 53 No. 1, pp. 85-110.

Bunch, B.S. (1996), "Current practices and issues in capital budgeting and reporting", Public Budgeting \& Finance, Vol. 16 No. 2, pp. 7-22.

Daunfeldt, S.-O. and Hartwig, F. (2015), “Capital budgeting practices in Spain”, BRQ Business Research Quarterly, Vol. 18 No.1, pp. 37-56. 
De Andrés, P., De Fuente, G. and San Martín, P. (2015), “Capital budgeting practices in Spain”, $B R Q$ Business Research Quarterly, Vol. 18 No. 1, pp. 37-56.

De Souza, P. and Lunkes, R.J. (2016), "Capital budgeting practices by large Brazilian companies", Contaduría y Administración, Vol. 61 No. 3, pp. 514-534.

Emmanuel, C., Harris, E. and Komakech, S. (2010), "Towards a better understanding of capital investment decisions", Joumal of Accounting and Organizational Change, Vol. 6 No. 4, pp. 477-504.

Farragher, E.J., Kleiman, R.T. and Sahu, A.P. (2001), "The association between the use of sophisticated capital budgeting practices and corporate performance", The Engineering Economist, Vol. 46 No. 4, pp. 300-311.

Garrison, R., Webb, A. and Libby, T. (2018), Managerial Accounting, McGraw-Hill Ryerson.

Gitman, L.J. and Forrester, J.R. Jr, (1977), "A survey of capital budgeting techniques used by major US firms", Financial Management, Vol. 6 No. 3, pp. 66-71.

Gitman, L.J., Juchau, R. and Flanagan, J. (2015), Principles of Managerial Finance, Pearson Higher Education AU.

Graham, J.R. and Harvey, C.R. (2001), "The theory and practice of corporate finance: evidence from the field", Journal of Financial Economics, Vol. 60 Nos 2/3, pp. 187-243.

Haka, S.F., Gordon, L.A. and Pinches, G.E. (1985), "Sophisticated capital budgeting selection technique and firms' performance", The Accounting Review, Vol. 60 No. 4, pp. 651-669.

Hall, J. and Millard, S. (2010), "Capital budgeting practices used by selected listed South African firms", South African Journal of Economic and Management Sciences, Vol. 13 No. 1, pp. 85-97.

Hermes, N., Smid, P. and Yao, L. (2007), "Capital budgeting practices: a comparative study of The Netherlands and China”, International Business Review, Vol. 16 No. 5, pp. 630-654.

Jog, M. and Srivastava, A. (1995), "Capital budgeting practices in corporate Canada”, Financial Practice and Education, Vol. 5 No. 2, pp. 37-43.

Katabi, R. and Dimoso, R. (2016), "The effect of small business characteristics on the choice of investment evaluation techniques for small and medium enterprises in Tanzania", Journal of Business Management, Vol. 18 No. 4, pp.11-18.

Kester, G. and Robbins, G. (2011), "The capital budgeting practices of listed Irish companies: insights from CFOs on their investment appraisal techniques", Accountancy Ireland, Vol. 43, pp. 28-30.

Kester, G.W., Chang, R.P., Echanis, E.S., Haikal, S., Isa, M.M., Skully, M.T., Tsui, K.-C. and Wang, C.J. (1999), "Capital budgeting practices in the Asia-Pacific region: Australia, Hong Kong, Indonesia, Malaysia, Philippines, and Singapore", Financial Practice and Education, pp. 25-33.

Khamees, B.A., Al-Fayoumi, N. and Al-Thuneibat, A.A. (2010), "Capital budgeting practices in the Jordanian industrial corporations", International Journal of Commerce and Management, Vol. 20 No. 1, pp. 49-63.

Lazaridis, I.T. (2004), "Capital budgeting practices: a survey in the firms in Cyprus", Journal of Small Business Management, Vol. 42 No. 4, pp. 427-433.

Leon, F.M., Isa, M. and Kester, G.W. (2008), "Capital budgeting practice of listed Indonesian companies", Asian Journal of Business and Accounting, Vol. 2 No. 1, pp. 175-192. PP. ISSN 19854064.

Mubashar, A. and Tariq, Y.B. (2019), "Capital budgeting decision-making practices: evidence from Pakistan”, Journal of Advances in Management Research, Vol. 16 No. 2, pp. 142-167.

Nurullah, M. and Kengatharan, L. (2015a), "Capital budgeting practices: evidence from Sri Lanka", Journal of Advances in Management Research, Vol. 12 No. 1, pp. 55-82.

Nurullah, M. and Kengatharan, L. (2015b), "Capital budgeting practices: evidence from Sri Lanka", Journal of Advances in Management Research., Vol. 12 No. 1,

Pike, R. and Neale, B. (2006), Corporate Finance and Investment: Decisions and Strategies, Pearson Education. 
Ross, S.A., Westerfield, R.W., Jordan, B. and Roberts, G. (2016), Corporate Finance, McGraw-Hill Ryerson.

Saunders, M., Lewis, P. and Thornhill, A. (2007), Research Methods for Business Students, 4th edition, Pearson Education Limited, Essex.

Segelod, E. (1998), “Capital budgeting in a fast-changing world”, Long Range Planning, Vol. 31 No. 4, pp. 529-525.

Shakila, Y. (2015), "Capital budgeting in practice: an explorative study on Bangladeshi companies", Int JEng Bus Enterp Appl, Vol. 11, pp. 158-163.

Shinoda, T. (2010), "Capital budgeting management practices in Japan: a focus on the use of capital budgeting methods", Economic Journal of Hokkaido University, Vol. 39, pp. 39-50.

Singh, S., Jain, P.K. and Yadav, S.S. (2012), "Capital budgeting decisions: evidence from India”, Journal of Advances in Management Research, Vol. 9 No. 1, pp. 96-112.

Verma, S., Gupta, S. and Batra, R. (2009), "A survey of capital budgeting practices in corporate India”, Vision: The Journal of Business Perspective, Vol. 13 No. 3, pp. 1-17.

\section{Corresponding author}

Md. Abdur Rouf can be contacted at: roufnakua@gmail.com

For instructions on how to order reprints of this article, please visit our website: 